\title{
IMPLEMENTASI MANAJEMEN PENINGKATAN MUTU BERBASIS SEKOLAH DI PONDOK PESANTREN TARBIYAH ISLAMIYAH PARIANGAN
}

\author{
Mulyadi \\ Program Pascasarjana STAIN Batusangkar \\ J I. Sudiman No. 137 Kuburajo LimaKaum Batusangkar
}

$+20$

\begin{abstract}
The purpose of this study was to determine the steps undertaken by the Implementing Regulation BS Pariangan TI MPMBS and find constraints - the constraints faced in the implementation OF MPMBS Boarding School Pariangan Tarbiyah Islamiyah. Research methods that researchers use qualitative date collection techniques, ( 1 ) observation, ( 2 ) interviews, and ( 3 ) study the documentation. The date were then analyzed in a way, data reduction, Presentation date, and giving a conclusion. The conclusion ofthis study isnecessaryactive role of allcomponentsthe existingat boarding schools. MPMBSImplementationcan be doneas expectedby theBoarding School. This studyalsogivesgreat meaningthatactiverole ofthe perpetratorsMPMBSat boarding schooland the allocation ofsufficientfunds, willbeimplementingMPMBSsuccess ofin theschoolandin theBoarding School.
\end{abstract}

Key Words: Implementasi, Manajemen peningkatan mutu.

\section{PENDAHULUAN}

Pondok Pesantren Tarbiah Islamiyah Pariangan merupakan salah satu dari Pondok Pesantren Tarbiyah Islamiyah yang sedang berupaya meningkatkan mutu pendidikannya, usaha tersebut terlihat dari manjemen yang diterapkannya. Adapun Manajemen yang diterapkan di Pondok Pesantren Tarbiyah Islamiyah Pariangan ini adalah Manajemen Peningkatan Mutu Berbasis Sekolah. Dalam penerepan Manajemen Peningkatan Mutu Berbasis Sekolah (MPMBS) dibutuhkan tahapan-tahapan (strategi) yang tepat agar MPMBS ini dapat berjalan dengan baik. Lebih lanjut E.Mulyasa menjelaskan bahwa
Kebutuhan akan aplikasi konsep strategic manjemen dan strategic planning dalam pengelolaan pendidikan itu sangat diperlukan. Aplikasi konsep tersebut diharapkan dapat mengurangi adanya stagnasi bagi aklerasi pembangunan pendidikan.(E. Mulyasa,2011:156).

Manajemen Peningkatan Mutu Berbasis Sekolah ini memiliki model yang berbeda dengan pola pengembangan yang selama ini di pakai oleh pihak sekolah seperti tahapantahapan yang dilakukan oleh karena tentu memiliki masalah-masalah atau kendalakendala dalam pengipliksiannya, Begitu juga dengan Pondok Pesantren Tarbiyah Islamiyah Pariangan yangmenerapkan Manajemen 
Peningkatan Mutu Berbasis Sekolah sebagaimanadianjurkan oleh pemerintah pusat.

Permalahan yang diangkat dalam tulisan ini adalah: Bagaimana Implementasi Manajemen Peningkatan Mutu Berbasis Sekolah di Pondok Pesantren Tarbiyah Islamiyah Pariangan? Sedangkan sub masalahnya adalah:

1. Bagaimanakah tahapan-tahapan yang dilakukan oleh Pondok Pesantren Tarbiyah Islamiyah Pariangan dalam Mengimplementasikan Manajemen Peningkatan Mutu Berbasis Sekolah?

2. Apa kendala-kendala yang menghambat terlaksananya Manajemen Peningkatan Mutu Berbasis Sekolah di Pondok Pesantren Tarbiyah Islamiyah Pariangan?

\section{METODE PENELITIAN}

Penelitian ini adalah penelitian lapangan dengan menggunakan pendekatan kualitatif. Dalam penelitian ini data yang hendak dikumpulkan adalah tentang Implementasi Manajemen Peningkatan Mutu Berbasis Sekolah di Pondok Pesantren Tarbiyah Islamiyah Pariangan. Data yang dibutuhkan dalam penelitian ini adalah Informasi yang bersifat deskriptif, karena itulah penelitian ini menggunakan pendekatan kualitatif.

Tempat penelitian adalah di Pondok Pesantren Tarbiyah Islamiyah Pariangan Kecamatan Pariangan Kabupaten Tanah Datar yang dilaksanakan dari bulan Desember 2013 sampai bulan Februari 2014.Sumber data utama dalam penelitian kualitatif ialah katakata dan tindakan, selebihnya merupakan data tambahan seperti dokumen dan sumber data yang lainnya.(Lexy Moleong, 2011:157).

Sumber data dalam penelitian ini adalah, Komite Sekolah, Pimpinan Pondok, kepala MAS TI Pariangan, Kepala MTs TI Pariangan, wakil kepala bidang Kurikulum, Wakil Kepala Bidang Sarana Prasarana, Wakil Kepala Bidang Humas, Wakil Kepala Bidang Kesiswaan, Kepala Tata Usaha, Guru, Peserta Didik (santri) dan wali peserta didik, Ninik Mamak, ilmuan-ilmuan disekitar Pondok, dan tokoh Masyarakat yang ada disekitar pondok.

Peneliti memilih Pimpinan pondok untuk menjadi informan utama, alasannya adalah karena dari informasi awal yang penulis peroleh melalui beberapa sumber di Pondok Pesantren Tarbiyah Islamiyah Pariangan Pimpinan Pondok merupakan bidang yang berkaitan langsung dengan fokus penelitian peneliti. Selain sumber data di atas penulis juga mengambil sumber data dari dokumendokumen yang ada di Pondok Pesantren Tarbiyah Islamiyah Pariangan seperti rencana kerja Pondok Pesantren, aturan-aturan dan hal-hal yang dianggap perlu untuk memperkuan temuan di lapangan.

Pengumpulan data menggunakan tiga cara yang paling umum dan paling sering digunakan dalam penelitian kualitatatif, yakni dengan observasi, wawancara dan dokumentasi (Emzir, 2011:). Dalam melakukan observasi tentang ImplementasiManajemen Peningkatan Mutu Berbasis Sekolah, hal-hal yang menjadi perhatian penulis adalahPerencanan, pelaksanaan serta evaluasi program Implementasi Manajemen Peningkatan Mutu Berbasis Sekolah di pondok Pesantren 
Tarbiyah Islamiyah Pariangan serta data-data yang lain untuk mendukung penelitian ini.

Fokus bahan wawancara yang penulis lakukan adalah menyangkut tentang sejarah berdirinya Pondok Pesantren Tarbiyah Islamiyah Pariangan, langkah-langkah penerapan Manajemen Peningkatan Mutu Berbasis sekolah yang dilaksanakan di Pondok Pesantren Tarbiyah Islamiyah Pariangan yang diarahkan untuk meningkatkan nilai jual/ saing Pondok Pesantren. Dan kendala-kendala yang menghambat terlaksananya Manajemen Peningkatan Mutu Berbasis Sekolah di Pondok Pesantren Tarbiyah Islamiyah.

Teknik pengumpulan data melalui dokumen adalah dengan mempelajari, menganalisa arsip-arsip kelengkapan di Pondok Pesantren Tarbiyah Islamiyah.Agar data yang telah diperoleh dalam penelitian ini dijamin tingkat validitasnya maka perlu dilakukan pengecekan atau pemeriksaan keabsahan data. Keabsahan data merupakan konsep penting yang diperbaharui dari konsep kesahihan (validitas) dan keandalan (reliabilitas) menurut versi positivisme dan disesuaikan dengan tuntutan pengetahuan, kriteria dan paradigmanya sendiri. (Lexy J Moleong, 2011: 321).

\section{PEMBAHASAN}

\section{Manajemen Peningkatan Mutu Berbasis Sekolah}

Manajemen Peningkatan Mutu Berbasis Sekolah (MPMBS) dapat di artikan sebagai Model manajemen yang memberikan otonomi lebih besar kepada pimpinan sekolah, dan mendorong partisipasi secara langsung warga sekolah, (guru,murid, kepala Sekolah, karyawan) dan masyarakat (Orang tua murid, Tokoh Masyarakat, Ilmuan, Pengusaha dan sebaginya) untuk meningkatkan mutu sekolah berdasarka Kebijaan pendidikan Nasional serta Peraturan Perundangan yang berlaku.(Veithzal Rivai dan Sylviana Murni, 2010:160).

Manajemen Peningkatan Mutu Berbasis Sekolah (MPMBS) didefinisikan sebagai proses manajemen sekolah yang diarahkan pada peningkatan mutu pendidikan, secara otonomi direncanakan, diorganisasikan, dilaksanakan, dan dievaluasi melibatkan semua stakeholder sekolah (Ibrahim Bafadal, 2006:82). Manajemen Peningkatan Mutu Berbasis Sekolah (MPMBS) juga dapat didefinisikan sebagai model manajemen yang memberikan otonomi lebih besar kepada sekolah dan mendorong sekolah untuk melakukan pengambilan keputusan secara partisipatif untuk memenuhi kebutuhan mutu sekolah atau untuk mencapai tujuan mutu sekolah dalam kerangka pendidikan nasional.

Secara operasional MPMBS dapat didefinisikan sebagai keseluruhan proses pendayagunaan keseluruhan komponen pendidikan dalam rangka peningkatan mutu pendidikan yang diupayakan sendiri oleh kepala sekolah bersama semua pihak yang terkait atau berkepentingan dengan mutu pendidikan.(Bafadal, 2006:84).Manajemen Peningkatan Mutu Berbasis Sekolah (MPMBS) dapat juga diartikan sebagai model manajemen yang memberikan otonomi lebih besar kepada Sekolah, memberikan fleksibilitas/keluwesankeluwesan kepada Sekolah, dan mendorong 
partisipasi secara langsung warga Sekolah (guru, siswa, kepala madrasah, karyawan) dan masyarakat (orangtua siswa, tokoh masyarakat, ilmuwan, pengusaha, dan lain-lain.) untuk meningkatkan mutu Sekolah berdasarkan kebijakan pendidikan nasional serta peraturan perundang-undangan yang berlaku.

Dengan otonomi yang lebih besar, maka Sekolah memiliki kewenangan yang lebih besar dalam mengelola sekolahnya, sehingga Sekolah lebih mandiri. Dengan kemandiriannya, Sekolah lebih berdaya dalam mengembangkan program-program yang, tentu saja, lebih sesuai dengan kebutuhan dan potensi yang dimilikinya. Dengan fleksibilitas/ keluwesan-keluwesannya, Sekolah akan lebih lincah dalam mengelola dan memanfaatkan sumberdaya madrasah secara optimal.

Beragamnya kebutuhan murid akan belajar, beragamnya kebutuhan guru dan staf dalam mengembangkan profesionalnya, berdaya lingkungan sekolah satu dengan lainnya. Dan ditambah beragamnya harapan orang tua/masyarakat akan pendidikan yang bermutu bagi anak dan bagi dunia usaha untuk memperoleh tenaga kerja yang bermutu.(Veithzal Rivai dan Sylviana Murni, 2010:160) Oleh sebab itu perlu dikembangkan Manajemen Peningkatan Mutu Berbasis Sekolah agar lembaga pendidikan mapu menjawab semua kebutuhan-kebutuhan masyarakat yang beragam.

\section{Tahapan-tahapan Manajemen Peningkatan Mutu Berbasis Sekolah}

Tahapan-tahapan implementasi MPMBS di atas juga sejalan dengan apa yang di kemukan Direktorat Jenderal Pendidikan Dasar dan Menengah tentang penerapan MPMBS di sekolah yaitu:

a. Penyusunan data dan profil sekolah yang komprehensif, akurat, valid, dan sistematis.

b. Melakukan evaluasi diri, menganalisis kelemahan dan kekuatan seluruh komponen sekolah.

c. Mengidentifikasi kebutuhan sekolah, merumuskan visi misi dan tujuan dalam rangka peningkatan kualitas pendidikan bagi siswa berdasarkan hasil evaluasi diri.

d. Menyusun program kerja jangka panjang dan jangka pendek sesuai dengan visi misi dan tujuan yang telah dirumuskan, yang diprioritaskan pada peningkatan mutu pendidikan.

e. Mengimplementasikan program kerja.

f. Melakukan monitoring dan evaluasi atas program kerja yang diimplementasikan; dan

g. Menyusun program lanjutan (untuk tahun berikutnya) atas dasar hasil monitoring dan evaluasi (Ibrahim Bafadal, 2006: 90).

Sedangkan tahapan-tahapan implementasi yang di kemukankan oleh Direktorat jenderalPeningkatan MutuPendidik dan Tenaga KependidikanKementerian pendidikan nasional2010, tahapan-tahapannya sebagai berikut:

\section{a. Melakukan Sosialisasi MPMBS}

Sekolah merupakan sistem yang terdiri dari unsur-unsur yang saling terkait dan karenanya hasil kegiatan pendidikan 
di sekolah merupakan hasil kolektif dari semua unsur sekolah. Dengan cara berpikir semacam ini, maka semua unsur sekolah harus memahami konsep MPMBS (apa, mengapa, dan bagaimana). Oleh karena itu, langkah pertama yang harus dilakukan oleh sekolah adalah mensosialiasikan konsep MPMBS kepada semua warga/unsur sekolah (guru, siswa, wakil kepala sekolah, guru BK, karyawan, orangtua siswa, pengawas, pejabat Dinas Pendidikan Kabupaten/Kota, pejabat Dinas Pendidikan Provinsi, dan sebagainya.) melalui berbagai mekanisme, misalnya seminar, lokakarya, pelatihan, diskusi, rapat kerja, simposium, forum ilmiah, dan media masa.

\section{b. Memperbanyak Mitra Sekolah}

Kemitraan penting untuk dilakukan karena disadari sepenuhnya bahwa hasil pendidikan sekolah merupakan hasil kolektif dari unsur-unsur terkait atau para pemangku kepentingan (stakeholders). Kemitraan yang dapat menghasilkan teamwork yang kompak, cerdas, dan dinamis merupakan kartu trup bagi keberhasilan MBS. Oleh karena itu, upaya-upaya untuk meningkatkan kemitraan perlu ditempuh melalui:(1) pembuatan pedoman mengenai tatacara kemitraan, penyediaan sarana kemitraan dan saluran komunikasi, (2) melakukan advokasi, publikasi, dan transparansi terhadap pemangku kepentingan, dan (3) melibatkan pemangku kepentingan sesuai dengan prinsip relevansi, yurisdiksi, dan kompetensi serta kompatibilitas tujuan yang akan dicapai. c. Merumuskan Kembali Aturan Sekolah, Peran Unsur-unsur Sekolah, yaitu:

a). Kebiasaan dan Hubungan antar Unsur-unsur Sekolah

b). Menerapkan Prinsip-prinsip Tata Kelola yang Baik

d. Menyusun Rencana Pengembangan Sekolah (RPS/RKAS), Melaksanakan, dan Memonitor serta Mengevaluasinya

e. Melakukan Monitoring dan Evaluasi RPS/RKAS. (Direktrorat Jendaral Peningkatan Mutu Pendidik dan Tenaga Kependidikan, 2010: 43-55)

Kendala-Kendala Penerpan Manajemen Peningkatan Mutu Berbasis Sekolah

Kendala-kendala yang dihadapi dalam mengimplementasikan MPMBS di atas dapat kita simpulkan sebagai berikut :

a. Tidak Berminat Untuk Terlibat

b. Tidak Efisisen

c. Pikiran kelompok

d. Memerlukan Pelatihan

e. Kebingungan atas peran dan tangggung jawab baru

f. Kesulitan koordinasi

\section{PONDOK PESANTREN}

Di Indonesia istilah kuttab lebih dikenal dengan istilah "pondok pesantren", yaitu suatu lembaga pendidikan islam yang didalamnya terdapat seorang kiai (pendidik) yang mengajar dan mendidik para santri (peserta didik) dengan sarana masjid yang digunakan untuk menyelenggarakan pendidikan terebut, serta didukung adanya pemondokan atau 
asrama sebagai tempat tinggal para santri.( Abdul,Mujib, 2006: 234-235).

Dalam kamus besar bahas Indonesia, pesantren diartikan sebagai asrama, tempat santri, atau tempat murid-murid belajar mengaji. Sedangkan secara istilah pesantren adalah lembaga pendidikan Islam, dimana para santri biasanya tinggal di pondok (asrama) dengan materi pengajaran kitab-kitab klasik dan kitab-kitab umum, bertujuan untuk menguasai ilmu agama Islam secara detail, serta mengamalkannya sebagai pedoman hidup keseharian dengan menekankan pentingnya moral dalam kehidupan bermasyarakat.

\section{Profil Pondok Pesantren Tabiyah Islamiyah Pariangan}

Pondok Pesantren Tarbiyah Islamiyah Pariangan yang didirikan oleh $\mathrm{H}$. Umar Bakri. Beliau bersama temannya Dt.Sidano, Dt. Ahmad Dirajo, Kharuzzaman, dan Umar Khatib MuliaPada tahun 1933. Pondok Pesantren Tarbiyah Islamiyah Pariangan bertempat di jorong Padang Panjang Pariangan Kecamatan Pariangan Kabupaten Tanah Datar, Provinsi Sumatera Barat. Pondok Pesantren Tarbiyah Islamiyah Pariangan memiliki gedung bertingkat, yang terdiri dari ruangan belajar, kantor majelis guru, kantor kepala Madrasah, ruang pustaka, Ruang UKS dan ruang konseling dan juga memilki pentilasi dan pencahaya yang cukup. Pondok Pesantren Tarbiyah Islamiyah Pariangan terletak di atas tanah seluas $734 \mathrm{~m}$ dengan luas bangunan $400 \mathrm{~m}$ dan luas halaman 334 m. Pondok Pesantren Tarbiyah Islamiyah Pariangan terletak sekitar: a. Dari ibu kota kecamatan berjarak \pm 2 Kilo Meter

b. Dari ibu kota kabupaten berjarak \pm 15 Kilo Meter

c. Dari ibu kota provinsi berjarak \pm 100 Kilo Meter

Pondok Pesantren Tarbiyah Islamiyah Pariangan adalah Pondok Pesantren Khalafi, dalam mengimplementasikan Manajemen Peningkatan Mutu Berbasis Sekolah (MPMBS) memiliki pengaturan tersendiri sesuai dengan situasi, kondisi dan keadaan lingkungan Pondok Pesantren dan lingkungan masyarakat. Pondok Pesantren juga mempertimbangkan kebijakan-kebijakan dari pemerintah yaitu Kementerian Agama dan Departemen Pendidikan. Semua tahapan/ prosedur pengimplementasian Manajemen Peningktan Mutu Berbasis Sekolah tidak terlepas dari nilai-nilai agama Islam.

Adapun tahapan/prosedur pengimplementasian manajemen peningkatan mutu berbasis sekolah yang dilaksanakan di Pondok Pesantren Tarbiyah Islamiyah Pariangan ini adalah:

a. Mensosialisasi Manajemen Peningkatan Mutu Berbasis Sekolah di Tarbiyah Islamiyah Pariangan.

Sosialisasi Peningkatan Mutu Berbasis Sekolah ini di sosialisasikan oleh Kemenag Tanah Datar agarguru-guru tidak jenuh,bosan dan dapat memahami dengan baik konsep dan bagaimana pelaksanaan MPMBS.

b. Penyusunan Data dan Profil Pondok Pesantren Tarbiyah Islamiyah Pariangan 
yang komprehensif, akurat, valid, dan sistematis.

Penyusunan data Pondok Pesatren dengan cara , menepatkan empat orang tenaga administrasi yang terdiri dari Kaur TU, Bendahara, dan dua orang Staf TU. Kaur TU secara umum bertugas sebagai perencana dan penanggung jawab pembuatan dan pengarsipan Data-Data Pondok Pesantren. Semetara Staf TU secara umum bertugas melaksankan pembuatan data yang dibutuhkan Pondok Pesantren dan pengarsipan data-data yang ada di Pondok Pesantren Tarbiyah Islamiyah Pariangan. Adapun secara khusus tugas Kaur TU, Bendahara, dan Staf TU sebagaimana tersusun dalam Topoksi Pondok Pesantren.

c. Melakukan Evaluasi Diri, Menganalisis Kelemahan dan Kekuatan Seluruh Komponen Pondok Pesantren.

Dalam penerapan Manajemen Peningkatan Mutu Berbasis Sekolah Pondok Pesantren terlebih dahulu melakukan Evaluasi diri Pondok Pesantren, untuk mengetahui kelemehan dan kekuatan delapan komponen dasar pondok yaitu evaluasi dibidang :

1) Standar sarana prasarana

2) Standar isi

3) Standara proses belajar

4) Standar penilaiyan atau evaluasi

5) Standar kopetensi kelulusan

6) Standar pengelolaan

7) Standar pendidik dan tenaga kependidikan
8) Standar pembiayaan

d. Mengidentifikasi Kebutuhan Pondok Pesantren Tarbiyah Islamiyah Pariangan, merumuskan Visi, Misi dan Tujuan dalam Rangka Peningkatan Kualitas Pendidikan bagi Siswa Berdasarkan Hasil Evaluasi Diri.

e. Menyusun Program Kerja Jangka Panjang dan Jangka Pendek yang Bermuatan Mutu.

f. Membuat Strategi Perencanaan dan Pengembangan Jangka Panjang.

g. Melakukan monitoring dan evaluasi

Kendala-kendala yang dihadapi oleh Pondok Pesantren Tarbiyah Islamiyah Pariangan dalam pengimplementasian Manajemen Peningkatan Mutu Berbasis Sekolah.

a. Kendala Dalam Sosialisasi Manajemen Peningktan Mutu Berbasis Sekolah

b. Kendala dalam penyusunan data dan profil Pondok Pesantren yang komprehensif, akurat, valid, dan sistematis.

c. Melakukan evaluasi diri, menganalisis kelemahan dan kekuatan seluruh komponen sekolah.

Menurut Wiwi Firdini, sebagai ketua tim evaluasi diri Pondok Pesantren Tarbiyah Islamiyah Pariangan, kendala yang di alami pada saat melakukan evaluasi adalah, kurang berminatnya warga Pondok Pesantren dalam melakukan evaluasi diri, karena evaluasi diri dianggab sebagai perbuatan yang menjelek-jelekan Pondok Pesantren. Sehingga hasil evaluasi yang semestinya di laporkan sebagaimana 
adanya. dilaporkan dengan melakukan perubahan-perubahan sementara. Setelah evaluasi selesai. selesai juga perubahan tersebut. Hal ini dilakukan Agar Pondok Pesantren masih terlihat baik-baik saja dan tidak perlu perobahan yang banyak untuk peningkatan mutu pada tahun selanjutnya. Hal-hal kecil yang dilakukan beberapa pihak ini sangat besar akibanya pada Pondok Pesantren dalam menentukan mana kekurangan dan kelebihan di Pondok Pesantren Tarbiyah Islamiyah Pariangan. Jelas hal ini juga menghambat peningkatann Mutu Pondok Pesantren kedepannya.

d. Menyusun Program Kerja Jangka Panjang Dan Jangka Pendek Sesuai Dengan Visi, Misi Dan Tujuan Yang Telah Dirumuskan, Yang Diprioritaskan Pada Peningkatan Mutu Pendidikan.

Kurangnya dana untuk sosialisasi penyususnan program kerja jangka panjang dan pendek, berakibat pada perumusan program jangka panjang dan program jangka pendek menjadi terburuburu. Atau kurang melibatkan komponenkomponen yang ada di Pondok Pesantren. terlebih kurangnya minat masyarakat dalam memberikan masukan dalam penyusunan program. Hal ini sesuai dengan apa yang di sampaikan oleh komite bahwa untuk urusan Program Kerja Pondok Pesantren mereka menyerahkan sepenuhnya pada Pimpinan Pondok Pesantren, kami nantinya akan membantu dalam hal pendanaan. Karena yang lebih tahu bagai mana Pondok Pesantren kedepannya adalah Pondok Pesantren itu sendiri

e. Membuat Strategi Perencanaan dan Pengembangan Jangka Panjang.

Dalam pembutan strategi perencanaan dan pengembangan jangka panjang hal yang mendasar sekali menghambat pembuatannya adalah masih banyaknya komponen-komponen Pondok Pesantren yang kurang faham akan pentingnya membuat strategi perencana dan pengembangan jangka panjang. Maka berkurangnyaide-ide yang muncul atau strategi penerapan monoton tampa invosi baru.

f. Melakukan Monitoring Dan Evaluasi Sebagaimana yang telah di uraikan di atas bahwa dalam monotoring yang dilakukan oleh Yayasan Al-hikmah Pariangan, Pimpinan Pondok Pesantren dan pengawas, kendala yang di hadapi adalah kurang berpadunya ide-ide Pimpinan Pondok dengan Pengawas yang ditugaskan Kamenag, dalam pengembangan sekolah kedepannya. Pimpinan Pondok lebih ingin fokus dalam pengembangan kurikulum Kepondokan (kitab kuning) namun pengawas dari Kameneg lebih memfokuskan pengebangan pada kurikulum dinas dan kurikulum Kamenag. Sehingga yang terjadi kurikulum Kameneg atau kurikulum Dinas dalam tahapan yang baik, sedangkan kurikulum Pondok Pessantren dalam tahap yang kurang baik. 


\section{PENUTUP}

Tahapan-tahapan Implementasi Manajemen Peningkatan Mutu Berbasis Sekolah di Pondok Pesantren

1. Sosialisasi Manajemen Peningktan Mutu berbasis Sekolah

2. Penyusunan data dan profil sekolah yang komprehensif, akurat, valid, dan sistematis. Di pondok pesantren telah dilakukan sebagai mana mestinya

3. Melakukan evaluasi diri, menganalisis kelemahan dan kekuatan seluruh komponen sekolah, namun belum berjalan maksimal

4. Mengidentifikasi kebutuhan sekolah, merumuskan visi, misi dan tujuan dalam rangka peningkatan kualitas pendidikan bagi siswa berdasarkan hasil evaluasi diri

5. Menyusun program kerja jangka panjang dan jangka pendek belum sepenuhnya sesuai dengan visi, misi dan tujuan yang telah dirumuskan, yang diprioritaskan pada peningkatan mutu pendidikan

6. Membuat strategi perencanaan dan pengembangan jangka panjang karena kurang optimalnya kerja sama setiap komponen pondok pesantren dan masih kurangnya dana.

7. Melakukan monitoring dan evaluasi diperlukan kerja sama yang lebih baik lagi antara stakeholder agar peningkatan mutu lebih terarah dan berkesinambungan

Hambatan-hambatan dalam Implementasi MPMBS di Pondok Pesantren a. Masih adanya komponen-komponen Pondok Pesantren yang tidak berminat untuk terlibat

b. Tidak Efisisen, pelaksanaan di tingkat Pondok Pesantren

c. Adanya Pikiran-pikiran kelompok yang menyulitkan Implementasi MPMBS di Pondok Pesantren Tarbiyah Islamiyah

d. Belum dilaksanakan Pelatihan-pelatihan Implementasi MPMBS di Pondok Pesantren

e. Kebingungan atas peran dan tangggung jawab baru

f. Sulitnya pesantren dalam berkoordinasi

Agar MPMBS di Pondok Pesantren Tarbiyah Islamiyah Pariangan dapat berjalan maksimal maka dapat disampaikan beberapa saran diantaranya sebagai berikut :

1. Diharapkan kepada Stake holder di Pondok Pesantren Tarbiyah Islamiyah Pariangan agar meningkatkan pemahaman akan pentingnya MPMBS.

2. Diharapkan kepada majelis guru, agar lebih meningkatkan peran aktifnya dalam mensukseskan implementasi MPMBS di pondok pesantren, seperti memberikan masukan atau ide-ide yang akan mungkin dicapai oleh sekolah, meningkatkan kemampuan guru dalam mengelola siswa/ lokal.

3. Diharapkan kepada masyarakat tidak hanya membantu dalam memecahkan masalah dana juga berperan aktif dalam memberikan masukan atas kebuuhan masyarakat yang bisadisediakan oleh Pondok Pesantren, agar Pondok Pesantren 
mampu menjawab tantangan dan kebutuhan masyrakat.

4. Kepada pemerintah khususnya Kamentrian Agama, diharapakan bantuanya agar monitoring MPMBS lebih maksimal, pengawas yang ditugaskan di Pondok Peantren haruslah yang berwawasan Pondok Pesantren.

\section{KEPUSTAKAAN ACUAN}

Abdul,Mujib, Ilmu Pendidikan Islam, Jakarta: Kencana Penada Media,2006.

Bogdan R and Biken Sk, Qualitative Research for Education, An Introduction to Theory and Method, Boston: Allyn and Bacon, 1982.
E. Mulyasa,Manajemen dan kepemimpinan kepala sekolah, Jakarta: Bumi Aksara, 2011.

Ibrahim Bafadal, Manajemen Peningkatan Mutu Sekolah Dasar, Jakarta:PT Bumi Aksara, 2006.

Lexy Moleong, Metodologi Penelitian Kualitatif, Bandung:Remaja Rosda Karya,1966.

Ruslan Ahmadi, Memahami penelitian Kualitatif, Malang: UIN Press, 2005.

Veithzal Rivai dan Sylviana Murni, Education Managemen, Jakarta: Raja Gtravfindo, 2010. 